\title{
Peningkatan NT-proBNP dan cTn-I Serum Pasien Limfoma Non-Hodgkin's yang Menerima Kemoterapi Berbasis Doxorubicin
}

\section{Elevation of NT-proBNP and cTn-I Serum in Non-Hodgkin's Lymphoma Patients after Doxorubicin-Based Chemotherapy}

\author{
Aditya Chandra $P^{1}$, Djoko Heri $H^{1}$, Wursito $^{2}$ \\ ${ }^{1}$ Laboratorium Ilmu Penyakit Dalam Rumah Sakit Umum Daerah Dr Saiful Anwar Malang \\ ²aboratorium IImu Kesehatan Jantung Rumah Sakit Umum Daerah Dr Saiful Anwar Malang
}

\begin{abstract}
ABSTRAK
Penelitian ini bertujuan menilai perubahan kadar cTn-I dan NT-proBNP serum pasien Limfoma Non-Hodgkin's (LNH) yang dikemoterapi berbasis doxorubicin (DOX). Penelitian menggunakan desain prospective cohort observational dengan kriteria inklusi yaitu pasien LNH usia $16 \mathrm{~s} / \mathrm{d} 65$ tahun, ECOG scale $\leq 2$, serum kreatinin $\leq 1,5 \mathrm{mg} / \mathrm{dl}$, dan fungsi liver normal. Kriteria eksklusi antara lain memiliki PJK, penyakit katup jantung dengan gangguan hemodinamik, ekokardiografi prekemoterapi LVEF $<50 \%$, sedang atau riwayat iradiasi di dinding thorax. Sampel darah diambil sebelum dan 24 jam setelah kemoterapi. Dari 34 pasien yang diteliti, lansia 20 pasien, dewasa 13 pasien dan 1 pasien remaja. Sebanyak 33 pasien dengan skor ECOG 1. Kadar cTn-I 23 pasien meningkat 24 jam pascakemoterapi ke-1 dan berbeda bermakna jika dibandingkan kadar cTn-I prekemoterapi $(p<0,001)$. Kadar NT-proBNP 11 pasien meningkat 24 jam pascakemoterapi ke-1 dan 22 pasien meningkat 24 jam pascakemoterapi ke-2. Kadar NT-proBNP pascakemoterapi ke-1 berbeda bermakna jika dibandingkan prekemoterapi $(p<0,001)$. Kadar NT-proBNP pascakemoterapi ke-2 berbeda bermakna jika dibandingkan prekemoterapi $(p<0,001)$. Kadar NT-proBNP dosis DOX $100 \mathrm{mg} / \mathrm{m}^{2}$ LPT berbeda bermakna jika dibandingkan dosis $50 \mathrm{mg} / \mathrm{m}^{2}$ LPT $(p=0,001)$. Uji regresi logistik menunjukkan usia tua berhubungan dengan risiko peningkatan NT-proBNP $(R R=6,271(\mathrm{Cl}: 1.295,30.382), p=0,023)$. Kesimpulannya, terdapat peningkatan kadar cTn-I dan NT-proBNP pada pasien LNH setelah kemoterapi berbasis DOX.
\end{abstract}

Kata Kunci: cTn-I, doxorubicin, Limfoma Non-Hodgkin's, NT-proBNP

\section{ABSTRACT}

This study aims to determine alteration in serum concentration of cTn-l and NT-proBNP in Non-Hodgkin's Lymphoma (NHL) patients treated with doxorubicin (DOX)-based chemotherapy. Using a prospective cohort observational design, data were collected from patients with NHL aged 16-65 years old, ECOG scale $\leq 2$, creatinine $\leq 1,5 \mathrm{mg} / \mathrm{dl}$, and normal liver function. Exclusion criteria were patient diagnosed with CHD, VHD with unstable hemodynamic, LVEF $<50 \%$ in echocardiography prior chemotherapy, irradiation on the chest wall. Blood samples were taken hours before and 24 after chemotherapy. In this study, there were 34 patients enrolled that were 20 elderly patients, 13 adults patients and 1 young adult patient. ECOG score in 33 patients was 1. The cTn-I levels increased at 24 hours after the first chemotherapy in 23 patients and were significantly different compared to the level prior to chemotherapy $(p<0,001)$. The NT-proBNP levels increased at 24 hours after the first chemotherapy in 11 patients and increased at 24 hours after the second chemotherapy in 22 patients. There were significant differences in the levels of NT-proBNP both after the first and second chemotherapy compared to the levels prior to chemotherapy ( $p<0,001 ; p<0,001$, respectively). NT-proBNP levels at dose of $100 \mathrm{mg} / \mathrm{m}^{2} \mathrm{DOX}$ were significantly different compared to the levels at dose of $50 \mathrm{mg} / \mathrm{m}^{2}(p=0,001)$. Logistic regression showed significant correlation between elderly with the risk of increased levels of in NT-proBNP (RR=6,271 (Cl: 1.295, 30.382), $p=0,023)$. In conclusion, there are elevations in the levels of cTn-I and NT-proBNP in patients with NHL underwent DOX chemotherapy.

Keywords: cTn-I, doxorubicin, Non-Hodgkin's lymphoma, NT-proBNP

Korespondensi: Aditya Chandra P. Laboratorium Ilmu Penyakit Dalam Rumah Sakit Umum Daerah Dr Saiful Anwar Malang, Jl. Jaksa Agung Suprapto No. 2 Tel. (0341) 366242 Email: aditya.cp79@yahoo.com 


\section{PENDAHULUAN}

Doxorubicin (DOX) yang mulai digunakan pada tahun 1960-an telah membuat kemajuan pada pengobatan kanker (1). Sampai saat ini pun DOX masih efektif sebagai obat anti-kanker dan banyak digunakan $(1,2)$. Optimisme ini kemudian memudar ketika manfaat klinis DOX dibatasi dosis kumulatif (2). DOX dapat menyebabkan jejas pada miokard dan yang berperan pada berkembangnya gagal jantung (HF) ireversibel, menurunkan kualitas hidup atau bahkan kematian (2-4).

Penyebab gangguan jantung yang disebabkan DOX multifaktorial. DOX meningkatkan bangkitan radikal bebas dan stres oksidatif yang berhubungan dengan jejas seluler. DOX berhubungan dengan penurunan antioksidan endogen yang bertanggung jawab menetralisir radikal bebas sedangkan kardiomiosit memiliki kapasitas antioksidan yang terbatas (5-9). Mekanisme lainnya dari DOX adalah menginduksi kematian termasuk apoptosis, akumulasi kalsium $\left(\mathrm{Ca}^{2+}\right)$ yang tinggi dalam mitokondria dan sitosol, dan modulasi ekspresi gen untuk sintesis protein di kardiomiosit (9-12).

Ekokardiografi adalah baku emas untuk deteksi kardiotoksisitas akibat obat kemoterapi. Meskipun demikian ekokardiografi tidak sensitif untuk menilai perubahan yang masih awal atau asimptomatik, membutuhkan waktu dan interprestasinya tergantung pemeriksa (13-15).

Baru-baru ini, biomarker jejas jantung banyak diselidiki untuk deteksi kardiotoksisitas. N-Terminal pro Brain Natriuretic Peptide (NT-proBNP) saat ini telah digunakan dalam membantu mendiagnosis gagal jantung $(13,16,17)$. Cardiac Troponin I (cTn-I) merupakan protein struktural penanda kerusakan miokard $(13,18,19)$. Dengan demikian dapat diasumsikan bahwa NT-proBNP dan cTn-I juga dapat juga mencerminkan kerusakan tahap awal pada miokard yang disebabkan oleh obat kemoterapi $(20,21)$. Buktibukti definitif peran diagnostik dan prognostik dalam konteks ini masih kurang dan biomarker tersebut belum secara rutin digunakan untuk pemantauan kardiotoksisitas dalam praktek klinis. Perdebatan masih berlangsung menyangkut berapa kadar NT-proBNP dan cTn-I untuk deteksi toksisitas jantung dan pada dosis kumulatif berapa DOX menimbulkan kardiotoksisitas $(20,21)$.

Analisis situasi di Divisi Hematologi-Onkologi Medik Bagian Ilmu Penyakit Dalam RSUD Dr. Saiful Anwar Malang, menunjukkan penggunaan DOX selalu meningkat setiap tahunnya. Pada tahun 2011 ada 118 kasus, tahun 2012 terdapat 188 kasus, dan tahun 2013 sebanyak 277 kasus yang sebagian besar adalah kasus limfoma maligna non hodgkins (LNH).

Fakta menunjukkan tingginya penggunaan DOX untuk terapi beberapa jenis penyakit kanker di RSUD Dr. Saiful Anwar Malang, dilain pihak untuk pemantauan kardiotoksisitas tidak dilakukan secara rutin. Oleh karena itu perlu dilakukan penelitian sejauh mana disfungsi jantung, melalui perubahan cTnl dan NT-proBNP, pada populasi yang mendapat kemoterapi DOX sekaligus melihat hubungan antara dosis kumulatif DOX dengan disfungsi jantung.

\section{METODE}

\section{Populasi Penelitian}

Penelitian ini menggunakan desain observasional prospective cohort. Populasi target adalah semua pasien dewasa yang terdiagnosis $\mathrm{LNH}$, menerima kemoterapi berbasis doxorubicin. Subjek memenuhi kriteria inklusi yaitu usia $16 \mathrm{~s} / \mathrm{d} 65$ tahun, memiliki performance status sesuai ZUBROD-ECOG-WHO scale $\leq 2$, serum kreatinin $\leq$ $1,5 \mathrm{mg} / \mathrm{dl}$, dan fungsi liver normal (SGOT<80 dan atau SGPT<80). Kriteria eksklusi antara lain memiliki riwayat penyakit jantung koroner (PJK), penyakit katub jantung dengan gangguan hemodinamik atau pada pemeriksaan ekokardiografi prekemoterapi didapatkan kelainan jantung dan LVEF $<50 \%$, sedang mendapatkan atau riwayat iradiasi di daerah dinding thorax. Penelitian dilakukan antara bulan April 2014 sampai dengan Desember 2014.

\section{Analisis Statistik}

Karakteristik dasar subjek penelitian ditampilkan dalam bentuk tabel. Variabel kategorik sampel disajikan dalam bentuk frekuensi dan persentase. Variabel numerik disajikan sebagai nilai mean dan standar deviasi jika distribusi data normal atau dalam bentuk median, batas minimum dan batas maksimum jika distribusi data tidak normal.

Perbedaan antara kadar cTnl prekemoterapi dan pascakemoterapi dinilai dengan uji Mc Nemar. Perbedaan antara kadar NT-proBNP prekemoterapi dengan pascakemoterapi dinilai dengan uji wilcoxon. Pengujian perbedaan kadar NT-proBNP berdasarkan dosis kumulatif doxorubicin $50 \mathrm{mg} / \mathrm{m}^{2}$ Luas Permukaan Tubuh (LPT) dan $100 \mathrm{mg} / \mathrm{m}^{2}$ LPT dilakukan dengan uji Mc Nemar. Penilaian hubungan antara variabel kelompok umur dan jenis kelamin terhadap peningkatan kadar biomarker jantung dilakukan dengan regresi logistik. Nilai p yang kurang dari 0,05 menunjukkan signifikansi. Analisis statistik dari data menggunakan program SPSS 14.0.

\section{Analisis Biokimia}

Pemeriksaan cTnI menggunakan metode ELISA rapid. Nilai $0,4 \mathrm{ng} / \mathrm{ml}$ adalah batas atas normal dari cTnl. Pemeriksaan NT-proBNP dengan Roche Elecsys 10. Serum yang dipisahkan dari darah kemudian disimpan pada suhu $80^{\circ} \mathrm{C}$. Pemeriksaan NT-proBNP dilakukan dalam kurun waktu 48 hari setelah sampel pertama dan satu hari setelah sampel terakhir diambil. Kadar $124 \mathrm{pg} / \mathrm{ml}$ adalah batas normal atas dari NT-proBNP.

\section{HASIL}

\section{Karakteristik Subjek}

Total sampel penelitian adalah 34 pasien. Populasi terbanyak adalah kategori umur lansia 20 pasien $(58,8 \%)$, diikuti kategori umur dewasa 13 pasien (38,2\%) dan terdapat 1 pasien yang masuk kategori remaja. Sebanyak 33 pasien (97,1\%) memiliki skor ECOG sama dengan 1. Semua sampel dikemoterapi dengan regimen Cyclophospamide, Vincristine, Doxorubicin, dan Prednison (CHOP) dengan 6 orang $(17,6 \%)$ mendapat tambahan terapi biologi (Rituximab). Karakteristik dasar subjek penelitian secara lengkap dapat dilihat pada Tabel 1 dan Tabel 2. 
Tabel 1. Karakteristik dasar sampel penelitian

\begin{tabular}{|c|c|c|c|c|c|}
\hline Karakteristik sampel & \multicolumn{2}{|c|}{ Jumlah (n) } & \multicolumn{3}{|c|}{ Frek. (\%) } \\
\hline \multicolumn{6}{|l|}{ Jenis kelamin } \\
\hline \multicolumn{3}{|l|}{ Pria } & 21 & \multicolumn{2}{|c|}{61,8} \\
\hline Wanita & & & 13 & \multicolumn{2}{|c|}{31,2} \\
\hline \multicolumn{6}{|l|}{ Umur } \\
\hline Remaja (16-25 th) & & & 1 & \multicolumn{2}{|c|}{2,9} \\
\hline Dewasa (26-45 th) & & & 13 & \multicolumn{2}{|c|}{38,2} \\
\hline Lanjut usia (46-65 th) & & & 20 & \multicolumn{2}{|c|}{58,8} \\
\hline \multicolumn{6}{|l|}{ Skor ECOG } \\
\hline skor 1 & & & 33 & \multicolumn{2}{|c|}{97,1} \\
\hline skor 2 & & & 1 & \multicolumn{2}{|c|}{2,9} \\
\hline \multicolumn{6}{|l|}{ Regimen kemoterapi } \\
\hline $\mathrm{CHOP}$ & & & 28 & \multicolumn{2}{|c|}{82,4} \\
\hline $\mathrm{R}-\mathrm{CHOP}$ & & & 6 & \multicolumn{2}{|c|}{17,6} \\
\hline \multicolumn{6}{|l|}{ Parameter klinis } \\
\hline $\mathrm{TDS} \pm \mathrm{SD}$ & \multicolumn{3}{|c|}{$125,1 \pm 9,23 \mathrm{mmHg}$} & & \\
\hline $\mathrm{TDD} \pm \mathrm{SD}$ & \multicolumn{3}{|c|}{$80,4 \pm 3,80 \mathrm{mmHg}$} & & \\
\hline Laju nadi \pm SD & \multicolumn{3}{|c|}{$70,4 \pm 2,07 \mathrm{bpm}$} & & \\
\hline $\mathrm{BMI} \pm \mathrm{SD}$ & \multicolumn{3}{|c|}{$20,9 \pm 1,63 \mathrm{~kg} / \mathrm{m}^{2}$} & & \\
\hline \multicolumn{6}{|c|}{$\begin{array}{l}\text { Keterangan: BMI: Body Mass Index; bpm: beat perminute; CHOP: } \\
\text { Cyclophospamide, Vincristine, Doxorubicin, dan Prednison; ECOG: R- } \\
\text { CHOP: Rituximab, Cyclophospamide, Vincristine, Doxorubicin, dan } \\
\text { Prednison; TDD: Tekanan darah Diastolik; TDS: Tekanan Darah Sistolik }\end{array}$} \\
\hline \multicolumn{6}{|c|}{$\begin{array}{c}\text { Tabel 2. Kadar biomarker (cTnl dan NT-proBNP) } \\
\text { prekemoterapi dan pascakemoterapi yang telah dilakukan uji } \\
\text { normalitas }\end{array}$} \\
\hline Variabel & Mean & Med. & SD & Min. & Maks. \\
\hline NT-proBNP prekemoterapi & & 49,95 & - & 12,20 & 375,20 \\
\hline NT-proBNP pascakemoterapi 1 & & 68,60 & - & 22,80 & 703,00 \\
\hline NT-proBNP pascakemoterapi 2 & - & 175,75 & - & 50,00 & 2902,6 \\
\hline cTn-I prekemoterapi & 0,13 & - & $\pm 0,19$ & - & - \\
\hline cTn-I pascakemoterapi & 0,55 & - & $\pm 0,30$ & - & - \\
\hline
\end{tabular}

\section{Cardiac Troponin I (cTn-I)}

Kadar cTn-I serum 23 pasien (67,6\%) meningkat 24 jam pascakemoterapi jika menggunakan batas normal atas 0,4 ug/dl. Pada Gambar 1 terlihat bahwa grafik sebaran kadar cTnl prekemoterapi cenderung berada pada nilai normal meskipun terjadi peningkatan usia tetapi grafik peningkatan kadar cTn-I serum terlihat setelah dilakukan kemoterapi.

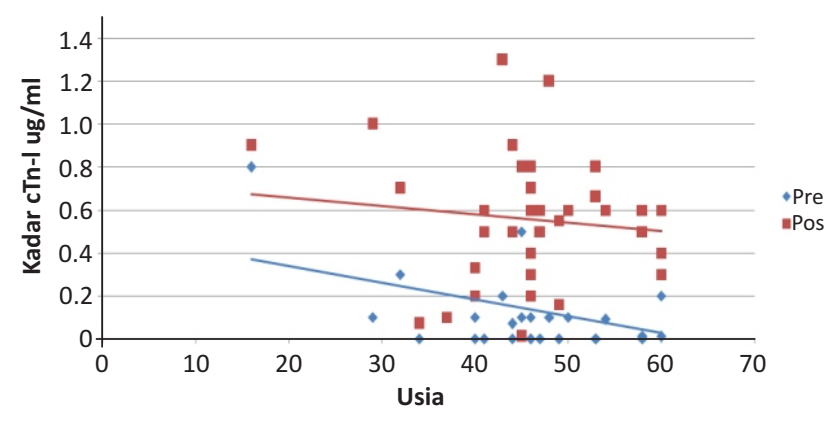

Gambar 1. Sebaran kadar cTnl prekemoterapi dan pascakemoterapi dibandingkan dengan usia

Uji bivariat untuk menilai perbedaan kadar cTnl prekemoterapi dengan cTnI pascakemoterapi menunjukkan terdapat peningkatan bermakna kadar cTnl serum pascakemoterapi jika dibandingkan dengan kadar cTnl serum prekemoterapi yang ditunjukkan dengan nilai $p<0,001$.

\section{NT-proBNP}

Kadar NT-proBNP serum 11 pasien (32,3\%) meningkat 24 jam post kemoterapi ke-1 dan 22 pasien (64,7\%) meningkat 24 jam pascakemoterapi ke-2 jika menggunakan batas normal atas $125 \mathrm{pg} / \mathrm{ml}$. Pada Gambar 2 terlihat kecenderungan peningkatan kadar NT-proBNP serum sebanding dengan peningkatan usia baik pada kadar NT-proBNP prekemoterapi maupun pascakemoterapi.

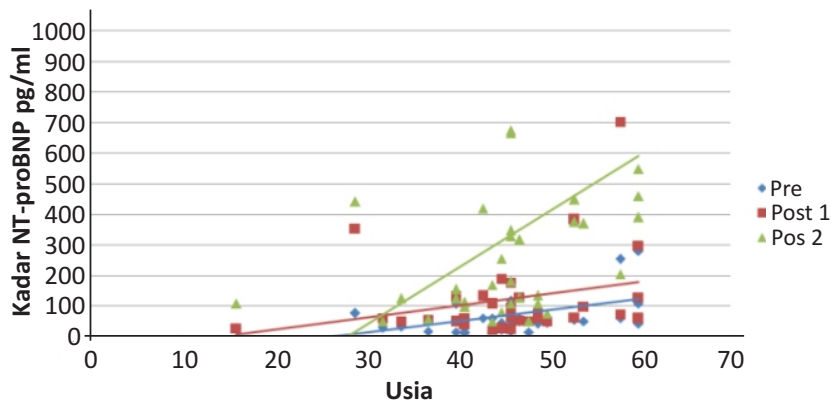

\section{Gambar 2. Sebaran kadar NT-proBNP prekemoterapi, pascakemoterapi ke-1 dan pascakemoterapi ke-2 dibandingkan dengan usia}

Pada pola pertama didapatkan 23 pasien dengan kadar NTproBNP tetap normal setelah kemoterapi ke-1 yang kemudian meningkat pada 11 pasien (47,8\%) setelah kemoterapi ke-2. Pola kedua: dari 8 pasien dengan kadar NT-proBNP serum meningkat setelah kemoterapi ke-1 dan kadarnya tetap tinggi pada 8 pasien (100\%) setelah kemoterapi ke- 2. Pola ketiga: 3 pasien dengan kadar NTproBNP serum prekemoterapi sudah meningkat yang selanjutnya pada 3 pasien (100\%) tersebut kadarnya tetap tinggi dalam serum setelah kemoterapi ke-1 dan kemoterapi ke 2 .

Diagram pada Gambar 3 menunjukkan kecenderungan secara individual bahwa kadar NT-proBNP serum akan tetap tinggi jika pada pemeriksaan sebelumnya hasilnya sudah meningkat.

Uji bivariat untuk menilai perbedaan kadar NT-proBNP prekemoterapi dengan NT-proBNP pascakemoterapi ke-1 dan ke-2 menunjukkan bahwa Kadar NT-proBNP serum pascakemoterapi ke-1 meningkat bermakna jika dibandingkan dengan kadar NT-proBNP serum prekemoterapi dengan nilai $p<0,001$. Kadar NT-proBNP serum pascakemoterapi ke-2 juga meningkat bermakna jika dibandingkan dengan kadar NT-proBNP serum prekemoterapi dengan nilai $p<0,001$.

Uji bivariat untuk menilai pengaruh dosis kumulatif DOX terhadap kadar NT-proBNP menunjukkan bahwa kadar NT-proBNP serum dosis kemoterapi $100 \mathrm{mg} / \mathrm{m}^{2}$ LPT meningkat bermakna jika dibandingkan dengan kadar NTproBNP serum dosis kemoterapi $50 \mathrm{mg} / \mathrm{m}^{2}$ LPT yang ditunjukkan dengan nilai $p$ sebesar 0,001. Dari hasil tersebut menunjukkan bahwa dosis kumulatif doxorubicin yang lebih tinggi berkaitan dengan peningkatan kadar NTproBNP serum. 


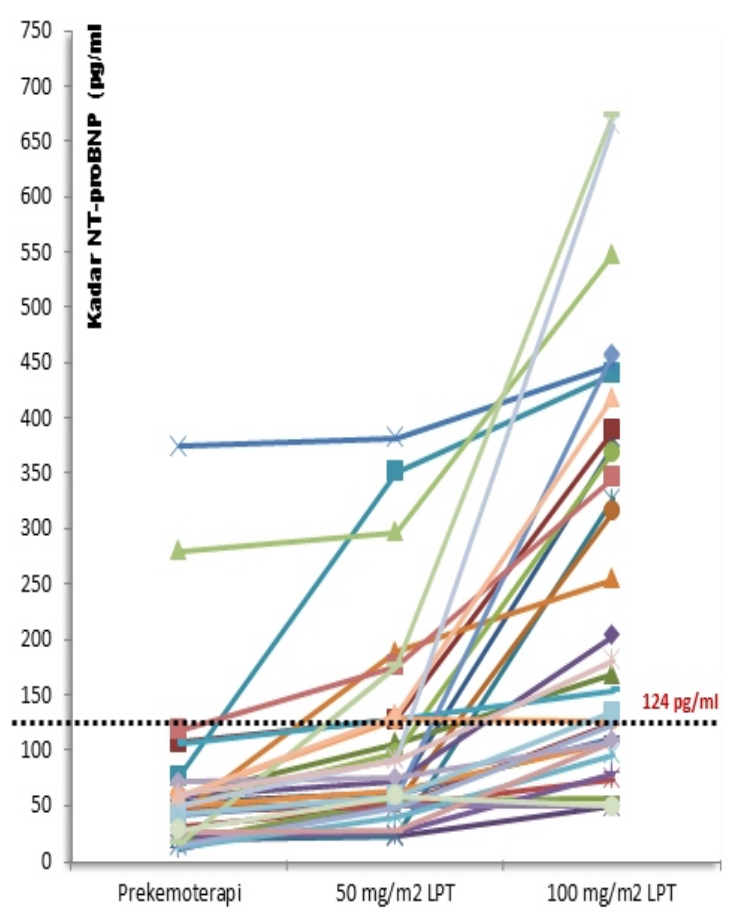

Gambar 3. Diagram dinamika perubahan kadar NT-proBNP pada tiap pasien dihubungkan dengan dosis kumulatif DOX. Prekemoterapi, pascakemoterapi dosis $50 \mathrm{mg} / \mathrm{m}^{2}$ LPT dan pascakemoterapi dosis $100 \mathrm{mg} / \mathrm{m}^{2}$ LPT.

\section{Hasil Uji Multivariat}

Uji regresi logistik untuk menilai hubungan dari jenis kelamin dan usia dengan kadar cTn-I dan NT-proBNP serum menunjukkan bahwa hanya usia yang berhubungan dengan risiko peningkatan kadar NT-proBNP serum dengan nilai $p<0,05 \quad(R R=6,271 \quad(C l: 1,295,30,382)$, $p=0,023$ ).

Tabel 3. Hasil analisis regresi logistik

\begin{tabular}{lrc}
\hline \multicolumn{1}{c}{ Variabel } & \multicolumn{1}{c}{ RR (CI) } & Nilai $\mathbf{p}$ \\
\hline cTn-I serum: & & \\
Jenis Kelamin & $0,361(0,80 ; 1,617)$ & 0,183 \\
Usia & $0,936(0,237 ; 3,701)$ & 0,925 \\
NT-proBNP serum: & & \\
Jenis Kelamin & $2,113(0,387 ; 11,552)$ & 0,388 \\
Usia & $6,271(1,295 ; 30,382)$ & 0,023 \\
\hline
\end{tabular}

\section{DISKUSI}

Dari 34 pasien LNH yang menjadi subyek penelitian, rerata umur pasien adalah 26 sampai dengan 65 tahun. Alexievia et al. melaporkan kejadian terbanyak LNH pada rentang usia 35 sampai dengan 64 tahun. Jenis kelamin terbanyak yang menjadi subyek penelitian ini adalah laki laki dengan perbandingan 1,7 kali lebih banyak dibanding wanita, ini sesuai dengan penelitian Zelenetz (2014) yang secara epidemiologi menyebutkan perbandingan insiden LNH antara laki-laki dengan perempuan adalah 1,4:1 (6,22).

Pedoman tatalaksana LNH dari NCCN 2014 menyebutkan bahwa kemoterapi berbasis DOX masih menjadi terapi lini pertama untuk LNH. Pada penelitian kami regimen kemoterapi yang digunakan berbasis DOX (CHOP) dan dilakukan penambahan terapi biologic agent anti CD20 (Rituximab) jika diperlukan (22). Pada penelitian ini semua pasien tidak pernah menerima kemoterapi dan radioterapi sebelumnya. Regimen kemoterapi dan jadwal pemberian DOX tidak bervariasi selama penelitian (tiap siklus adalah 21 hari).

Penelitian-penelitian sebelumnya telah mendefinisikan kardiotoksisitas yang diinduksi kemoterapi jika telah terjadi gagal jantung. Witteles et al, menyebutkan insiden kardiotoksisitas terjadi bervariasi mulai dari $7 \%$ sampai dengan $40 \%$ sesuai dosis yang diberikan (23). Pemantauan kardiotoksisitas DOX secara sederhana dapat dilakukan dengan menggunakan parameter EKG, ekokardiografi dan radionuclide ventriculography. Tetapi alat diagnostik tersebut tidak sensitif ketika digunakan untuk mendeteksi kerusakan miokard yang masih awal dan asimptomatik. Penyelidikan dengan menggunakan metode yang lebih sensitif telah menyebabkan definisi kardiotoksisitas menjadi lebih luas $(14,15)$.

Beberapa penelitian telah melaporkan peran biomarker jantung tersebut untuk deteksi lebih awal kardiotoksisitas pada pasien dewasa yang diterapi dengan DOX $(17,18,20)$. Pada penelitian ini, peran biomarker jantung cTn-I dan NTproBNP diselidiki pada kelompok pasien LNH dewasa yang mendapat kemoterapi berbasis DOX sampai dengan pemberian kemoterapi ke-2. Pengamatan kejadian jejas akut pada jantung dinilai dengan peningkatan kadar biomarker jantung dalam serum sebelum dan 24 jam sesudah kemoterapi.

Hasil pengamatan pada penelitian kami menunjukkan 23 pasien LNH $(67,6 \%)$ mengalami peningkatan bermakna kadar cTn-I serum dalam 24 jam setelah pemberian kemoterapi berbasis DOX. Sparano et al, (2001) dan Witteles et al, (2011) melaporkan bahwa waktu puncak terdeteksinya cTn-I dalam darah adalah 10 sampai dengan 24 jam setelah terjadinya jejas akut dari kardiomiosit, mengindikasikan terjadinya nekrosis miokardium, derajat peningkatan berkaitan dengan kerusakan kardiomiosit tetapi tidak berkaitan dengan dosis kumulatif DOX yang diberikan $(23,24)$. Penelitian dari Horacek et al, (2014) pada pasien-pasien dengan kadar troponin serum yang positif setelah kemoterapi berkaitan dengan peningkatan cardiac event dalam tahun pertama tindak lanjut (21). Hasil uji cTn-I yang terus-menerus negatif menunjukkan risiko kardiotoksisitas terendah (nilai prediksi negatif 99\%) (21). Penelitian oleh Cardinal (2000) berkesimpulan bahwa pemeriksaan cTn-I cukup sensitif, spesifik, memiliki nilai prediksi yang tinggi dan ekonomis untuk menilai jejas akut kardiomiosit (25).

Penelitian oleh Horacek melaporkan bahwa usia sangat muda, usia lanjut dan jenis kelamin wanita merupakan faktor yang meningkatkan risiko kardiotoksisitas (21). Pada penelitian ini didapatkan bahwa peningkatan bermakna kadar cTn-I lebih banyak pada kelompok usia lanjut, tetapi risiko peningkatan cTn-I pada semua kelompok umur tidak berbeda bermakna (OR: 0,936, p: 0,925). Pada penelitian ini peningkatan kadar cTn-I serum lebih banyak pada lakilaki tetapi risiko peningkatannya pada kedua jenis kelamin tidak berbeda bermakna (OR: 0,361, p: 0,183). Faktor yang menimbulkan perbedaan ini kemungkinan karena sampel wanita yang jumlahnya kurang $(p<0,05)$.

Miokardium yang mengalami jejas progresif akibat DOX lambat laun akan mengalami disfungsi dan berakhir 
dengan gagal jantung simptomatik $(20,26)$. Penelitian ini juga mengevaluasi kegunaan NT-proBNP sebagai penanda awal yang prediktif untuk disfungsi jantung yang diinduksi DOX.

Hasil penelitian kami menunjukkan bahwa peningkatan kadar NT-proBNP serum dipengaruhi jumlah dosis kumulatif DOX. Ekstein et al, menilai kadar NT-pro BNP serum pasien selama kemoterapi DOX dan didapatkan kadar NT-proBNP lebih tinggi bermakna dibandingkan dengan kontrol setelah dosis pertama DOX yang lebih dari $25 \mathrm{mg} / \mathrm{m}^{2}$ LPT (27). Penelitian oleh Schmitt menyebutkan kejadian kardiotoksisitas pada dosis $138 \mathrm{mg}(\mathrm{SD} \pm 26 \mathrm{mg}$ ) (28). Penelitian dari Hayakawa et al, pada 34 pasien yang dilakukan evaluasi setelah terapi DOX menyebutkan bahwa 8 dari 34 pasien tersebut menunjukkan disfungsi jantung (melalui pemeriksaan ekokardiografi). Kelompok ini memiliki kadar BNP lebih tinggi bermakna $(p<0,05)$ dan menerima dosis kumulatif DOX lebih tinggi $(p<0,01)(29)$.

Penelitian kami mendapatkan 3 pola yang berbeda dari perbandingan kadar NT-proBNP serum prekemoterapi dan pascakemoterapi. Volkova et al, (2005) melaporkan bahwa pasien dengan peningkatan persisten kadar NT-proBNP pada 72 jam setelah kemoterapi berkembang menjadi beberapa bentuk gangguan jantung selama 12 bulan pengamatan, dengan hubungan yang bermakna antara memburuknya nilai diastolik dan sistolik dengan meningkatnya NT-proBNP (1). Peningkatan persisten kadar NT-proBNP serum mencerminkan adanya pengurangan cadangan fungsional miokard atau berkurangnya toleransi jantung pada obat-obatan kardiotoksik dan timbulnya aktivasi neurohormonal $(25,29)$.

Penelitian ini juga mengkonfirmasi bahwa peningkatan kadar NT-proBNP didapatkan secara bermakna lebih banyak pada kelompok usia lanjut dengan risiko peningkatan sebanyak 6 kali dibanding kelompok usia dewasa $(R R=6.271 ; \mathrm{Cl}(1,295,30,382), p=0,023)$.

\section{DAFTAR PUSTAKA}

1. Volkova M and Russel R. Anthracycline Cardiotoxicity: Prevalence, Pathogenesis and Treatment. Current Cardiology Reviews. 2011; 7(4): 214-220.

2. Visani G, Isidori A, and Minotti G. Anthracycline Cardiotoxicity. In: Veselka J (Ed). Cardiomyopathy From Basic Research to Clinical Management. Rijeka, Crotia: Intech; 2012: pp. 621-644.

3. Haoyi Z, Boris K, Stuart K, and Spreyer JL. Cardiac Effects of Cancer Therapy. In: Neiderhuber JE, Armitage JO, Doroshow JH, Kastan MB, and Tepper JE (Ed). Abeloffs Clinical Oncology Fifth Edition. Philadelphia: Elsevier Inc.; 2014: pp. 858-873.

4. Shaikh AS, Saleem AF, Mohsin SS, Alam MM, and Ahmed MA. Anthracycline-Induced Cardiotoxicity: Prospective Cohort Study from Pakistan. British Medical Journal. 2013; 3(11): 1-7.

5. Mizutani H, Tada-Oikawa S, Hiraku Y, Kojima M, and Kawanishi S. Mechanism of Apoptosis Induced by Doxorubicin Through the Generation of Hydrogen Peroxide. Life Sciences. 2005; 76(13): 1439-1453.

6. Alexieva B, Sainova IV, Pavlova VG, Markova T, and Nikolova EB. Insights Into Mechanisms of Doxorubicin Cardiotoxicity. Journal of Physiology and
Sedangkan peningkatan kadar NT-proBNP pada kedua jenis kelamin tidak berbeda $(\mathrm{RR}=2,113 ; \mathrm{Cl}(0,387,11,552)$, $p=0,388)$. Groothuis et al, (2009) dan Amal et al, menyimpulkan bahwa usia (anak atau sangat tua), durasi terapi dan dosis kumulatif DOX merupakan faktor risiko peningkatan NT-proBNP $(28,30)$.

Sampai saat ini peran biomarker untuk deteksi kardiotoksisitas yang akut masih menjadi perdebatan. Kardiotoksisitas akut yang subtle, tidak terdeteksi dengan ekokardiografi dan atau gejala dan tanda klinis tetapi pada banyak penelitian didapatkan telah terjadi peningkatan kadar NT-pro-BNP dan cTn-I. Evaluasi ekokardiografi saat akhir terapi DOX untuk mengetahui korelasi dengan peningkatan akut kadar NT-proBNP menarik untuk diketahui. Soker dan Germanakis telah menemukan hubungan yang bermakna dari NT-proBNP serum dengan kelainan pada ekokardiografi. Namun demikian, median evaluasi dengan ekokardiografi dalam rentang antara satu bulan hingga 9 tahun setelah kemoterapi berakhir (28).

Penelitian kami memiliki beberapa keterbatasan. Keterbatasan pertama adalah terbatasnya jumlah pasien, kedua adalah jumlah pasien yang proporsinya tidak merata di antara 3 kelompok usia dan jenis kelamin. Terakhir adalah sampel yang diperiksa adalah sampel simpan yang rentang waktu penyimpanan sampel tiap pasien berbeda.

Penelitian ini telah menunjukkan bahwa baik cTn-I maupun NT-proBNP serum mengalami peningkatan pasca pemberian kemoterapi DOX. Perubahan ini dapat merupakan penanda awal yang berguna untuk memprediksi kemungkinan kardiotoksisitas yang disebabkan DOX. Penelitian prospektif lebih lanjut diperlukan untuk mengklarifikasi apakah kedua penanda tersebut memberikan informasi yang prediktif, apakah kombinasi kedua biomarker tersebut lebih baik dan membantu dalam mengidentifikasi populasi yang berisiko tinggi mengalami kardiotoksisitas.

7. Rochette L, Guenancia C, Gudjoncik A, et al. Anthracyclines/Trastuzumab: New Aspects of Cardiotoxicity and Molecular Mechanisms. Trends in Pharmacological Sciences. 2015; 36(6): 326-348.

8. Heide RSV and L'Ecuyer TJ. Molecular Basis of Anthracycline Induced Cardiotoxicity. Journal of Heart and Metabolism. 2007; 35: 1-4.

9. Montaigne D, Hurt C, and Neviere R. Mitochondria Death/Survival Signaling Pathways in Cardiotoxicity Induced by Anthracyclines and Anticancer-Targeted Therapies. Biochemistry Research International. 2012; 10: 1-12.

10. Rasola A and Bernardi P. Mitochondrial Permeability Transition In $\mathrm{Ca}^{2+}$ - Dependent Apoptosis and Necrosis. Cell Calcium. 2011; 50(3): 222-233.

11. Octavia Y, Tocchetti CG, Gabrielson KL, Janssens $S$, Crijns HJ, and Moen AL. Doxorubicin-Induced Cardiomyopathy: from Molecular Mechanisms to Therapeutic Strategies. Journal of Molecular and Cellular Cardiology. 2012; 52(6): 1213-1225.

12. Gammella E, Maccarinelli F, Buratti P, Recalcati S, and Cairo G. The Role of Iron in Anthracycline Cardiotoxicity. Frontiers in Pharmacology. 2014; 5: 1- 
6.

13. Kinova E and Goudev A. Early Detection and Prediction of Cardiotoxicity - Biomarker and Echocardiographic Evaluation. In: Fiuza M (Ed). Cardiotoxicity in Oncologic Treatments. Rijeka, Croatia: Intech; 2012: pp. 154-183.

14. Plana JC, Galderesi M, Barac A, et al. Expert Consensus for Multimodality Imaging Evaluation of Adult Patients During and After Cancer Therapy: A Report from the American Society of Echocardiography and the European Association of Cardiovascular Imaging. Journal of American Society of Echocardiography. 2014; 27(9): 911-939.

15. Bonnie K. Role of Echocardiography in Patients Treated with Cardiotoxic Drugs. In: Sutton MSJ and Wiegers SE (Eds). Echocardiography in Heart Failure. Philadelphia: Elsevier Inc.; 2011: pp. 141-145.

16. Slavin L, Daniels LB, and Maisel AS. The Use of Biomarkers in the Evaluation of Heart Failure. In: Mann D and Felker GM (Eds). Heart Failure: A Companion to Braunwald's Heart Disease Second Edition. Philadelphia: Saunders; 2014: pp. 545-559.

17. Gaggin HK and Januzzi JL. Natriuretic Peptides in Heart Failure and Acute Coronary Syndrome. Clinics in Laboratory Medicine. 2014; 34(1): 43-58.

18. Puja P and Jeremias A. Elevated Cardiac Troponin in the Absence of Acute Coronary Syndromes: Mechanism, Significance, and Prognosis. In: Allen Jeremias (Ed). Cardiac Intensive Care Second Edition. Philadelphia: Saunders; 2014: pp. 196-202.

19. Borkowski BJ, Cheema Y, Shahbaz AU, Bhattacharya SK, and Weber KT. Cation Dyshomeostasis and Cardiomyocyte Necrosis: The Fleckenstein Hypothesis Revisited. European Heart Journal. 2011; 32(15): 1846-1853.

20. Dolci A, Dominici R, Cardinale D, Sandri MT, and Panteghini M. Biochemical Markers for Prediction of Chemotherapy-Induced Cardiotoxicity: Systematic Review of the Literature and Recommendations for Use. American Journal Clinical Pathology. 2008; 130(5): 688-695.

21. Horacek JM, Vasatova M, Pudil R, et al. Biomarkers for the Early Detection of Anthracycline-Induced Cardiotoxicity: Current Status. Biomedical papers of the Medical Faculty of the University Palacký, Olomouc, Czechoslovakia.. 2014; 158(4): 511-517.

22. Zelenetz AD, Gordon LI, Wierda WG, et al. Non Hodgkins Lymphoma. Journal of the National Comprehensive Cancer Network. 2014; 12(6): 916-946.

23. Witteles RM, Fowler MB, and Telli ML. Chemotherapy-Associated Cardiotoxicity: How Often does It Really Occur and How Can It Be Prevented? Heart Failure Clinics. 2011; 7(4): 333-344.

24. Sparano ACJA, Wolff, and Brown D. Troponins for Predicting Cardiotoxicity from Cancer Therapy. Lancet. 2000; 356(9246): 1947-1948.

25. Nousiainen T, Vanninen E, Jantunen E, et al. Natriuretic Peptides during the Development of Doxorubicin-Induced Left Ventricular Diastolic Dysfunction. Journal of Internal Medicine. 2002; 251(3): 228-234.

26. Sawaya H, Sebag IA, Plana JC, et al. Assessment of Echocardiography and Biomarkers for the Extended Prediction of Cardiotoxicity in Patients Treated with Anthracyclines, Taxanes, and Trastuzumab. Circulation, Cardiovascular Imaging. 2012; 5(5): 596603.

27. Ekstein S, Nir A, Rein A, et al. N-Terminal-pro B-Type Natriuretic Peptide as a Marker for Acute Anthracycline Cardiotoxicity in Children. Journal of Pediatrics Hematology/Oncology. 2007; 29(7): 440444.

28. Mavinkurve-Groothuis AM, Groot-Loonen J, Bellersen L, et al. Abnormal NT-Pro-BNP Levels In Asymptomatic Longterm Survivors Of Childhood Cancer Treated With Anthracyclines. Pediatrics Blood Cancer. 2009; 52(5): 631-636.

29. Hayakawa $\mathrm{H}$, Komada $\mathrm{Y}$, Hirayama $\mathrm{M}$, Hori $\mathrm{H}$, Ito $\mathrm{M}$, and Sakurai M. Plasma Levels of Natriuretic Peptides in Relation to Doxorubicin-Induced Cardiotoxicity and Cardiac Function in Children with Cancer. Medical and Pediatric Oncology. 2001; 37(1): 4-9.

30. Zidan A, Sherief LM, El-sheikh A, et al. NT-proBNP as Early Marker of Subclinical Late Cardiotoxicity After Doxorubicin Therapy and Mediastinal Irradiation in Childhood Cancer Survivors. Disease Markers. 2015; 19: 1-10. 